\title{
Overview of relation between coverage of health services and maternal mortality in East Java Province in 2015
}

\author{
Wahyul Anis', Kuntoro², Soenarnatalina Melaniani \\ 'Midwifery Study Program, Faculty of Medicine, Universitas Airlangga \\ ${ }^{2}$ Faculty of Public Health, Universitas Airlangga
}

\begin{abstract}
ABSTRAK
Tujuan: menganalisis upaya pelayanan kesehatan ibu yang dapat mempengaruhi Angka Kematian Ibu.

Bahan dan Metode: Penelitian dilakukan di Dinas Kesehatan Provinsi Jawa Timur dengan menggunakan data sekunder dari 38 kabupaten/kota di Jawa Timur tahun 2015 yang meliputi capaian cakupan kunjungan hamil $\mathrm{K} 1$ dan $\mathrm{K} 4$, kunjungan ibu nifas, deteksi dini komplikasi pada ibu hamil oleh tenaga kesehatan, pertolongan persalinan di tenaga dan fasilitas kesehatan, penanganan komplikasi oleh tenaga kesehatan dan AKI. Data dianalisis dengan regresi spasial dan digambarkan dengan peta tematik aplikasi statistik ArcView.

Hasil: AKI tertinggi berada di Kabupaten Bojonegoro, Lumajang, Probolinggo, Bondowoso, Situbondo dan kota Probolinggo. Beberapa kabupaten/kota yang memiliki kematian ibu tertinggi mempunyai kedekatan wilayah yaitu Kabupaten Lumajang, Probolinggo, Bondowoso, Situbondo dan Kota Probolinggo. Adanya kedekatan lokasi dapat disimpulkan adanya hubungan keadaan dan faktor penyebab AKI antar kabupaten sehingga bisa dikaji lebih mendalam tentang faktor penyebab AKI baik dari sosial budaya maupun karakteristik geografisnya. Pencapaian cakupan pelayanan kesehatan ibu untuk semua kabupaten/kota di Provinsi Jawa Timur tidak banyak perbedaan.

Simpulan: AKI di kabupaten/kota provinsi Jawa Timur tahun 2015 tidak banyak dipengaruhi oleh pelayanan kesehatan ibu sehingga perlu penelitian lebih lanjut tentang penyebab lain dari AKI di kabupaten/kota Provinsi Jawa Timur.
\end{abstract}

\begin{abstract}
Objectives: to analyze the efforts of maternal health services that may affect maternal mortality rate.

Materials and Methods: The study was conducted at the Health Office of East Java using secondary data from 38 districts/cities in East Java in 2015 that includes performance antenatal care K1 and $\mathrm{K} 4$, postnatal care, early detection of complications in pregnant women, natal in health workers and health facilities, management of complications by health workers and MMR. Data were analyzed with statistical method with spatial regression and illustrated with thematic maps by application ArcView statistics. Results: the highest MMR was in Bojonegoro district, Lumajang, Probolinggo, Bondowoso, Situbondo and Probolinggo city. Some districts/cities that have the highest maternal mortality has proximity of areas, namely the district Lumajang, Probolinggo, Bondowoso, Situbondo and Probolinggo city. Their proximity concluded an association condition and the causes of MMR between districts so they can be studied more in depth about the causes of MMR kind of social, cultural and geographical characteristics. The coverage maternal health services to all districts/cities in East Java province is not much difference.

Conclusion: the maternal mortality rate in the district/city of East Java province in 2015 was not much affected by maternal health services so we need more research on other causes of MMR in districts/city of East Java Province.
\end{abstract}

Keywords : health services and maternal mortality rate

Kata kunci: pelayanan kesehatan dan angka kematian ibu

Correspondence: Wahyul Anis, Midwifery Study Program, Faculty of Medicine, Universitas Airlangga, Jalan Prof dr Moestopo 47, Surabaya, 60131,phone: 62-31-5020252 ext.161.Email: wahyul.anis@yahoo.com

\section{INTRODUCTION}

Maternal Mortality Rate (MMR) is a number that indicates the death of a woman occuring during pregnancy until 42 days after childbirth regardless the duration and place of pregnancy, and the death is not due to an accident but because of her pregnancy, childbirth and postpartum state. ${ }^{1}$ MMR is an indicator to measure the health of families, especially the health of mothers in certain regions. ${ }^{2}$ Indonesia has a higher maternal mortality rate compared to other countries in Asia. In 2007 maternal mortality rate in Indonesia is 228 per 100,000 live births, while in Singapore only 6 per 100,000 live births, Brunei 33 per 100,000 live births, Philippines 112 per 100,000 live births as well as Malaysia and Vietnam both achieving MMR of 160 per 100,000 live births. ${ }^{3}$ Indonesian Demographic Health
Survey in 2012 reported that maternal mortality rate in Indonesia rose from 228 per 100,000 live births in 2007 to 357 per 100,000 births in $2012 .^{4}$ East Java Provincial Health Office in 2013 reported maternal mortality rate in East Java province was 97.39 per 100,000 live births. This number did not significantly decrease from the previous year in 2012, which reached 94.43 per 100,000 live births. The cause of high MMR in East Java is medical factors that included preeclampsia/eclampsia, bleeding, infection and heart disease. ${ }^{5}$

The Indonesian government and community have role and responsibility towards the mother's health, especially in facilitating mothers to have adequate access to health care since the mother's health status can also be influenced by the quality of health services. Indicators of maternal health services include maternal health care, 
laboring mother's health care, postpartum maternal health services, service/handling of maternal complications and contraceptive services. Each attempt of maternal health services' success rate can be measured through the performance coverage which includes pregnant women's visit to health service (K1 and K4), early detection of high risk pregnant women by health personnel, coverage of deliveries in health facilities, coverage of postpartum visit to health facilities and complications treatment by health personnel. ${ }^{6}$

Health services that already run this far requires monitoring and evaluation to determine whether or not the service indicator being used today is appropriate and may reduce MMR. If the service indicator is not appropriate then there must be changes or modifications toward the maternal health services' indicators that can be explained by a significant indicator of maternal health services that can influence the MMR so that the efforts to increase the coverage of maternal health services will contribute to the maternal mortality rate in Indonesia.

\section{MATERIALS AND METHODS}

This study used secondary data drawn from the Health Department of East Java province in 2015. The research data covered pregnant women visit (K1 and K4), early high-risk detection by health personnels, deliveries in health personnels and health facilities, maternal postpartum visits to health facilities, coverage of maternal complications that handled by health professionals and mother mortality rate in all districts in the East Java province in 2015 . The collected data was then analyzed using spacial regression test so that the data can be presented with thematic maps using ArcView application. The result can be concluded by viewing the map. If the district/city's map had the same color and were located close to each other, it could be concluded that there were some similarities in geographic characteristics, population, health behaviors, health services, customs and so on.

\section{RESULTS AND DISCUSSION}

The achievement of maternal health services described with a bar chart that includes $\mathrm{K} 1, \mathrm{~K} 4$ coverage, early detection of high risk by health personnels, deliveries by health personnels and in health facilities, postpartum women's visit and handling of complications by health personnels in all districts/cities in East Java province in 2015, do not differ much, but the color gradation in district/city map shows a clear difference. High maternal mortality is shown by dark red color which can be found in Bojonegoro district, Lumajang, Probolinggo, Bondowoso, Situbondo and Probolinggo city, while lower MMR can be found in Pacitan district, Magetan, Kediri, Pamekasan and Sumenep. Thematic map shows that neighboring districts/cities tend to have same maternal mortality rates, while only a small portion of neighboring areas do not have similar gradation color. Similarity shown by neighboring districts/cities can be further studied so that social, cultural and geographic factors in maternal mortality rate can be discovered.

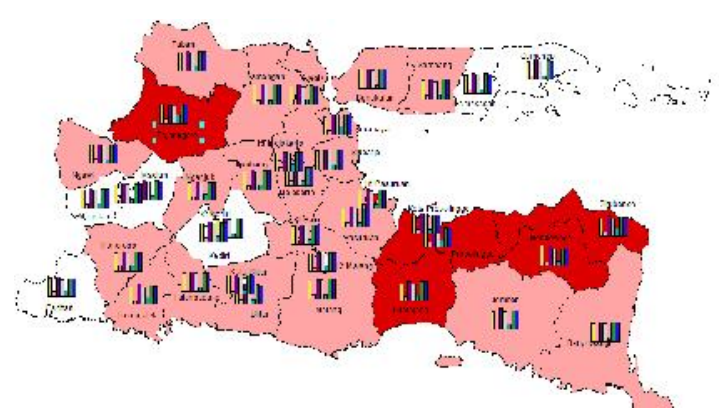

Figure 1. Thematic map of maternal health services and MMR in districts/cities of East Java province in 2015

Notes:

Colors at the district/city showing percentage of Maternal Mortality in the districts/cities of East Java Province in 2015 were categorized into three shades of red color. Colors criteria based on the percentage of MMR are as follows:

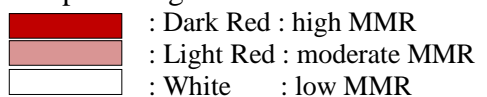

Bar chart in the map shows maternal health service in each district and city with colors as follows :

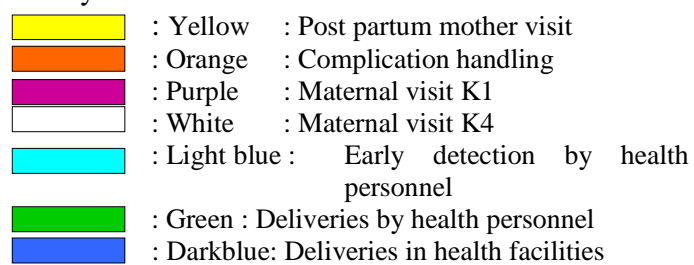

Maternal health services of East Java province in 2015 could be explained by a bar chart on a thematic map, and it can be concluded that all disricts and cities in East Java province has similar materal service' coverage's rate. The bar chart explains that the average rates of maternal visit (K1, K4), delivery by health personnel and health facilities as well as postpartum visit service are all more than $90 \%$, while coverage for early detection of high risk pregnant women service done by health professionals and handling of complications are still low. 
An increasing percentage of maternal deaths is not directly related to maternal health services which include visits, early detection of complications by medical personnel, delivery by health personnel and health facilities, postpartum visit and handling of complications by health personnels for example in Situbondo district. Situbondo district has a high maternal mortality rate in East Java province, although the data of maternal health services coverage is higher compared to other districts/cities in East Java province. There has not any significant relation between the maternal health services coverage and maternal mortality, which due to health service that still focus on improving the quantitiy of health care services not the quality of services. Maternal mortality is also influenced by many factors other than health care, such as a economic, social, cultural factors and so on. The absence of correlation between the health care coverage with maternal death is because other factors are influencing maternal service such as medical factors, economic factors, socio-cultural factors and so on. ${ }^{7}$

WHO explained that complications occuring in women could be prevented by good quality service, not only service coverage because coverage can not describe the changes that occur in the mother's mortality rate. Quality of service can be measured from the inputs, human resources, processes and activities in providing service and activity results which are usually issued in the form of health effects for example the maternal mortality rate. Health care, according to the WHO, does not only emphasize to what extent health service follows clinical pathways for example the effectiveness of ecidence based services, time efficiency and patient's safety services, and documentation management. ${ }^{8}$ Indicators of maternal health services must be evidencebased and therefore the health service will be able to decrease maternal mortality rate.

There are many factors affecting maternal mortait rate other than health services. The direct causes of maternal mortality are such as bleeding, hypertension in pregnancy, infections and other diseases, while indirect causes include late referrals, social and cultural factors and so on. About $15 \%$ of pregnancy and delivery will experience complications. Most of these complications can be life-threatening, but most complications can be prevented and handled with if the mother immediately seek medical aid, health personnel perform appropriate treatment procedures, health personnels were able to early identify complications, health personnels were able to give first aid if complications occur and to stabilize patients before referring, the referral process is effective and the hospital services are efficient and effective. $^{9}$ If all of these services can be applied maternal mortality can be prevented.

\section{CONCLUSION}

Coverage of maternal health services is not significantly related to the occurrence of many maternal deaths. It could be caused by many health services which still focus on quantity instead of quality of service hence, in East Java province year 2015, an increase in maternal care coverage is not offset by a decrease in maternal mortality rate. Contionus monitoring and evaluation on maternal health services are needed, not only the services' quantity but also the services' quality so that that the quality of maternal health services and cross sector support can contribute to reduce of maternal mortality rate, in East Java as well as in Indonesia

\section{REFERENCES}

1. Sarwono P. Ilmu Kebidanan. Jakarta: Bina Pustaka Sarwono Prawihardjo; 2008.

2. Profil Statistik Kesehatan. Jakarta: Badan Pusat Statistik; 2013.

3. Survey Demografi dan Kesehatan Indonesia. Jakarta: Badan Pusat Statistik; 2013.

4. Profil Kesehatan Indonesia. Jakarta: Kementrian Kesehatan RI; 2012.

5. Profil Kesehatan Provinsi Jawa Timur. Surabaya: Dinas Kesehatan Provinsi Jawa Timur; 2013.

6. Profil Kesehatan Indonesia. Jakarta: Kementrian Kesehatan RI; 2014.

7. UNICEF Indonesia. Ringkasan Kajian Kesehatan Ibu dan Anak. Diakses di www.unicef.org/.../id/ UNICEF_Annual_Report_(Ind)_130731.pdf. 2012. Diakses 29 Mei 2016.

8. WHO and Partnership for Maternal, Newborn and Child Health. Consultation on Improving Measurement of the quality of Maternal, Newborn and Child Care in Health Facilities. France: WHO Library Cataloguing -in-Publication; 2013.

9. Rencana Aksi Percepatan Penurunan Angka Kematian Ibu di Indonesia. Jakarta: Direktorat Bina Kesehatan Ibu Ditjen Bina Gizi dan KIA Kementrian Kesehatan RI; 2013. 